Research Article

\title{
High-Efficiency Photochemical Water Splitting of CdZnS/CdZnSe Nanostructures
}

\author{
Chen-I Wang, Zusing Yang, Arun Prakash Periasamy, and Huan-Tsung Chang \\ Department of Chemistry, National Taiwan University, 1, Section 4, Roosevelt Road, Taipei 106, Taiwan \\ Correspondence should be addressed to Huan-Tsung Chang; changht@ntu.edu.tw
}

Received 19 December 2012; Accepted 5 February 2013

Academic Editor: Alfonso Castiñeiras

Copyright (C) 2013 Chen-I Wang et al. This is an open access article distributed under the Creative Commons Attribution License, which permits unrestricted use, distribution, and reproduction in any medium, provided the original work is properly cited.

\begin{abstract}
We have prepared and employed $\mathrm{TiO}_{2} / \mathrm{CdZnS} / \mathrm{CdZnSe}$ electrodes for photochemical water splitting. The $\mathrm{TiO} / \mathrm{CdZnS} / \mathrm{CdZnSe}$ electrodes consisting of sheet-like CdZnS/CdZnSe nanostructures $(8-10 \mu \mathrm{m}$ in length and $5-8 \mathrm{~nm}$ in width) were prepared through chemical bath deposition on $\mathrm{TiO}_{2}$ substrates. The $\mathrm{TiO}_{2} / \mathrm{CdZnS} / \mathrm{CdZnSe}$ electrodes have light absorption over the wavelength $400-$ $700 \mathrm{~nm}$ and a band gap of $1.87 \mathrm{eV}$. Upon one sun illumination of $100 \mathrm{~mW} \mathrm{~cm}^{-2}$, the $\mathrm{TiO}_{2} / \mathrm{CdZnS} / \mathrm{CdZnSe}$ electrodes provide a significant photocurrent density of $9.7 \mathrm{~mA} \mathrm{~cm}^{-2}$ at $-0.9 \mathrm{~V}$ versus a saturated calomel electrode (SCE). Incident photon-tocurrent conversion efficiency (IPCE) spectrum of the electrodes displays a maximum IPCE value of $80 \%$ at $500 \mathrm{~nm}$. Moreover, the $\mathrm{TiO}_{2} / \mathrm{CdZnS} / \mathrm{CdZnSe}$ electrodes prepared from three different batches provide a remarkable photon-to-hydrogen efficiency of $7.3 \pm 0.1 \%$ (the rate of the photocatalytically produced $\mathrm{H}_{2}$ by water splitting is about $172.8 \mathrm{mmol} \cdot \mathrm{h}^{-1} \cdot \mathrm{g}^{-1}$ ), which is the most efficient quantum-dots-based photocatalysts used in solar water splitting.
\end{abstract}

\section{Introduction}

Developing environmentally clean energy resources from abundant solar energy has attracted considerable attention these years [1]. Hydrogen production by photochemical water splitting is a promising route because hydrogen has the highest energy density values per mass $\left(140 \mathrm{MJ} \mathrm{kg}^{-1}\right)$ and its oxidation product $\left(\mathrm{H}_{2} \mathrm{O}\right)$ is more eco-friendly [24]. Hitherto, many semiconductors with band-gap energy exceeding the oxidation potential of water $(1.23 \mathrm{~V}$ versus normal hydrogen electrode (NHE)) at $\mathrm{pH} 1.0$ have been employed for water splitting [5]. Albeit metal oxides including $\mathrm{TiO}_{2}, \mathrm{ZnO}$, and their derivatives are the most common photocatalysts used in water splitting, yet they provide low overall photon-to-hydrogen efficiency $(\eta)$ attributed to their wide band gaps $[6,7]$. To overcome these limitations, doping other metal or inorganic ions to $\mathrm{TiO}_{2}$ and $\mathrm{ZnO}$ materials has been demonstrated [8]. However, this strategy is not quite successful, mainly because their band gaps are greater than $2.0 \mathrm{eV}(620 \mathrm{~nm})$ [9], whereas photocatalysts having band gaps less than $2.0 \mathrm{eV}$ can absorb solar light in the visible to nearinfrared region more efficiently.
Quantum dots (QDs) such as CdTe [10], CdS [11-13], and CdSe [14-18] have been anchored to $\mathrm{TiO}_{2}$ and $\mathrm{ZnO}$ electrodes to harvest visible light for more efficient water splitting. Photoelectrochemical cells (PECs) incorporating QDssensitized $\mathrm{TiO}_{2}$ electrodes provide several advantages: (i) ease of fabrication, (ii) generation of multiple electron/hole [19], (iii) high visible light harvesting capability in solar spectrum, and (iv) tunable band gaps due to the quantum size effect of QDs. Remarkably, CdTe-sensitized ZnO nanowire electrodes provided a superior $\eta$ of $1.83 \%$ relative to that of $\mathrm{ZnO}$ nanowires $(0.66 \%)$ in a nonsacrificial electrolyte [10]. Under white light illumination of $100 \mathrm{~mW} \mathrm{~cm}^{-2}$, CdS/CdSe QDssensitized $\mathrm{ZnO}$ nanowire electrodes and $\mathrm{TiO}_{2}$ electrodes had high photocurrent densities of 12 and $14.9 \mathrm{~mA} \mathrm{~cm}^{-2}$, respectively [14-18]. Although PECs featuring QDs-sensitized $\mathrm{TiO}_{2}$ and $\mathrm{ZnO}$ electrodes provided greater $\eta$ values for water splitting than corresponding bare electrodes, their $\eta$ values are still less than $4 \%$ [11-13]. Moreover, an external potential is mandatory to separate the charges efficiently to prevent the recombination of electron-hole pair under illumination [20].

Therefore, to fabricate highly efficient PECs for water splitting, we prepared $\mathrm{TiO}_{2} / \mathrm{CdZnS} / \mathrm{CdZnSe}$ electrodes from 
$\mathrm{Cd}\left(\mathrm{NO}_{3}\right)_{2}, \mathrm{ZnSO}_{4}, \mathrm{Na}_{2} \mathrm{~S}$, and $\mathrm{Na}_{2} \mathrm{SeSO}_{3}$ via chemical bath deposition (CBD) approach [21]. Under AM 1.5 illumination $\left(100 \mathrm{~mW} \mathrm{~cm}^{-2}\right)$ and in presence of a sacrificial electrolyte $\left(2 \mathrm{M} \mathrm{Na}_{2} \mathrm{~S}\right.$ and $\left.0.25 \mathrm{M} \mathrm{Na}_{2} \mathrm{SO}_{3}\right)$, the three as-prepared $\mathrm{TiO}_{2} / \mathrm{CdZnS} / \mathrm{CdZnSe}$ electrodes provided $\eta$ of $7.3 \pm 0.1 \%$. To the best of our knowledge, this is the most efficient QDssensitized electrode used in solar water splitting.

\section{Materials and Methods}

2.1. Chemicals and Instrumentation. Cadmium nitrate, commercially available P-25 $\mathrm{TiO}_{2}$ powders (Degussa), ethylene glycol, methyl cellulose, nitric acid, potassium chloride, poly (vinylpyrrolidone) (PVP, $M_{w}$ 55,000), polyethylene glycol $\left(M_{w} 5,000\right)$, selenium powder, sodium hydroxide, sodium sulfide, sodium sulfite, and zinc sulfate were purchased from Sigma-Aldrich (Milwaukee, WI, USA). Fluorine-doped tin oxide (FTO) glass was obtained from Plasma Technology (Taoyuan, Taiwan).

2.2. Preparation of $\mathrm{TiO}_{2}$ Electrodes. A repetitive dry method was used to prepare the $\mathrm{TiO}_{2}$ electrodes [21]. In brief, $\mathrm{TiO}_{2}$ paste was prepared by mixing $\mathrm{TiO}_{2}$ powder (after $\mathrm{HNO}_{3}$ treatment; $0.6 \mathrm{~g})$, PVP $(0.18 \mathrm{~g})$, methyl cellulose $(0.06 \mathrm{~g})$, and ultrapure $\mathrm{H}_{2} \mathrm{O}(3 \mathrm{~mL})$. The paste $(0.05 \mathrm{ml})$ was then applied to one of the bare edges of a FTO glass; it was flattened by sliding a glass rod over the tape-covered edges. A single-layer $\mathrm{TiO}_{2}$ electrode was obtained after drying at $50^{\circ} \mathrm{C}$ in an oven for $1 \mathrm{~h}$. The process was repeated to obtain a double-layer $\mathrm{TiO}_{2}$ electrode with a thickness of $20 \mu \mathrm{m}$.

2.3. Preparation of $\mathrm{TiO}_{2} / \mathrm{CdZnS}_{(m)} / \mathrm{CdZnSe} e_{(n)}$ Electrodes. The as-prepared $\mathrm{TiO}_{2}$ electrodes each with an effective area of $1 \mathrm{~cm}^{2}$ were immersed into a solution $(2 \mathrm{~mL})$ containing $\mathrm{Cd}\left(\mathrm{NO}_{3}\right)_{2}(0.5 \mathrm{M})$ and $\mathrm{ZnSO}_{4}(0.75 \mathrm{M})$ for $5 \mathrm{~min}$, rinsed with ultrapure $\mathrm{H}_{2} \mathrm{O}(1 \mathrm{~mL})$, and dried with an air gun. They were then dipped for $5 \mathrm{~min}$ into an aqueous solution $(2 \mathrm{~mL})$ of $0.5 \mathrm{M} \mathrm{Na}_{2} \mathrm{~S}$, and then rinsed with ultrapure $\mathrm{H}_{2} \mathrm{O}(1 \mathrm{~mL})$, and finally dried with an air gun. The process was repeated up to $m$ cycles ( $m$ is integer 1 7). These as-prepared electrodes are designated herein as $\mathrm{TiO}_{2} / \mathrm{CdZnS}_{(m)}$ electrodes. The $\mathrm{TiO}_{2} / \mathrm{CdZnS}_{(m)}$ electrodes were further dipped into a solution of $\mathrm{Cd}\left(\mathrm{NO}_{3}\right)_{2}(0.5 \mathrm{M})$ and $\mathrm{ZnSO}_{4}(0.75 \mathrm{M})$ for $5 \mathrm{~min}$ at $27^{\circ} \mathrm{C}$ and then immersed into aqueous $\mathrm{Na}_{2} \mathrm{SeSO}_{3}(0.08 \mathrm{M})$ at $50^{\circ} \mathrm{C}$ for $60 \mathrm{~min}$ followed by rinsing with ultrapure $\mathrm{H}_{2} \mathrm{O}$ and then dried with an air gun. The process was repeated up to $n$ cycles ( $n$ is integer $1 \sim 4$ ). The as-prepared electrodes are designated as $\mathrm{TiO}_{2} / \mathrm{CdZnS}_{(m)} / \mathrm{CdZnSe}_{(n)}$ electrodes.

2.4. Preparation of $\mathrm{TiO}_{2} / \mathrm{CdZnS}_{(m)} / \mathrm{CdZnSe}{ }_{(n)} / \mathrm{ZnS}$ Electrodes. The as-prepared $\mathrm{TiO}_{2} / \mathrm{CdZnS}_{(m)} / \mathrm{CdZnSe}(n)$ electrodes were immersed separately into $\mathrm{ZnSO}_{4}$ solution $(0.5 \mathrm{M})$ for $5 \mathrm{~min}$, rinsed with ultrapure $\mathrm{H}_{2} \mathrm{O}$, and dried with an air gun. They were then dipped for 5 min into aqueous $\mathrm{Na}_{2} \mathrm{~S}$ solution $(0.5 \mathrm{M})$ followed by rinsing with ultrapure $\mathrm{H}_{2} \mathrm{O}$ and dried with an air gun. The as-prepared electrodes are represented as $\mathrm{TiO}_{2} / \mathrm{CdZnS}_{(m)} / \mathrm{CdZnSe}_{(n)} / \mathrm{ZnS}$ electrodes.
2.5. Measurements. The UV-vis absorption spectra of the as-prepared electrodes were recorded using a Cary $100 \mathrm{UV}$ Vis spectrophotometer from Varian (Palo Alto, CA, USA). Scanning electron microscopy (SEM) images and energy dispersive spectra (EDS) were recorded using an S-2400 SEM system from Hitachi (Tokyo, Japan). Cyclic voltammetry (CV) tests were performed using a CHI 700D electrochemical analyzer ( $\mathrm{CH}$ Instruments, Austin, TX, USA). CV measurements of the $\mathrm{TiO}_{2} / \mathrm{CdZnS}_{(m)} / \mathrm{CdZnSe}_{(n)}$ electrodes (effective area: $1.0 \mathrm{~cm} \times 1.0 \mathrm{~cm}$ ) were performed using a threeelectrode system: a $\mathrm{TiO}_{2} / \mathrm{CdZnS}_{(m)} / \mathrm{CdZnSe}_{(n)}$ electrode as a working electrode, a Pt counter electrode, and an SCE as a reference electrode. $\mathrm{CV}$ measurement was carried out in a solution containing $2.0 \mathrm{M} \mathrm{Na} \mathrm{N}_{2} \mathrm{~S}$ and $0.25 \mathrm{M} \mathrm{Na}_{2} \mathrm{SO}_{3}$. The solution was purged by nitrogen to remove dissolved oxygen before the experiment. The irradiation source was a 450-W xenon arc lamp (Oriel, Stratford, CT, USA) equipped with an AM 1.5 filter. A commercially available silicon-based reference cell (Oriel, Stratford, CT, USA) was employed to measure the light intensity $\left(100 \mathrm{~mW} \mathrm{~cm}^{-2}\right)$. Incident photon-to-electron conversion efficiency (IPCE) spectra were recorded using a PEC-S20 instrument (Peccell Technologies, Kanagawa, Japan). Photocatalytic hydrogen generation experiments have been carried out in a labmade photochemical reactor. A typical glass cell consisted of photoanode $\left(\mathrm{TiO}_{2} / \mathrm{CdZnS}_{(m)} / \mathrm{CdZnSe}_{(n)}\right)$ and cathode $(\mathrm{Pt}$ foil) that were connected by a fine porous glass frit. The $\mathrm{H}_{2}$ produced in our experiments was measured by applying a gas volume headspace method.

\section{Results and Discussion}

3.1. Properties of Electrodes. The CBD layers of QDs play a significant role in light harvesting [22], so we investigated the role that the amounts (layers) of $\mathrm{CdZnS}$ and $\mathrm{CdZnSe}$ nanostructures played in determining the $\eta$ values (Scheme 1). Moreover, upon increasing $\mathrm{CdZnS}_{(m)} / \mathrm{CdZnSe}_{(n)}$ layer numbers, the light absorption increased and reached a maximum value at $m=5$, and $n=2$ (not shown). The as-prepared $\mathrm{TiO}_{2} / \mathrm{CdZnS}_{(5)} / \mathrm{CdZnSe}_{(2)}$ electrode absorbs light in the wavelength range of 400-700 $\mathrm{nm}$ (Figure 1(a)). The band gap corresponding to the absorption edge of this electrode was $1.87 \mathrm{eV}(662 \mathrm{~nm})$ [23]. This value is in the range of 1.23-2.0 eV, validating it as a suitable photocatalyst for water splitting $[5,9-18]$. The existence of $\mathrm{Cd}, \mathrm{Zn}, \mathrm{S}, \mathrm{Se}, \mathrm{Ti}$, and $\mathrm{O}$ components in the as-prepared electrode was further confirmed from energy dispersive spectroscopy (EDS) results (Figure 1(b)). The scanning electron microscopy (SEM) image (inset to Figure 1(b)) elucidates that the as-resulting electrode was decorated with sheet-like nanostructures, having lengths of $8-10 \mu \mathrm{m}$ and widths of $5-8 \mathrm{~nm}$, respectively. The crosssectional view of the photoelectrode is shown in Figure 2, which reveals that sheet-like nanostructures are not only found on the surface but also deeply embedded within the film as denoted by the dotted circles.

The electrodes were tested for solar water splitting in presence of sacrificial electrolyte $[24,25]$ consisting of $\mathrm{Na}_{2} \mathrm{~S}$ and $\mathrm{Na}_{2} \mathrm{SO}_{3}$. The use of $\mathrm{Na}_{2} \mathrm{~S} / \mathrm{Na}_{2} \mathrm{SO}_{3}$ mixture provided 


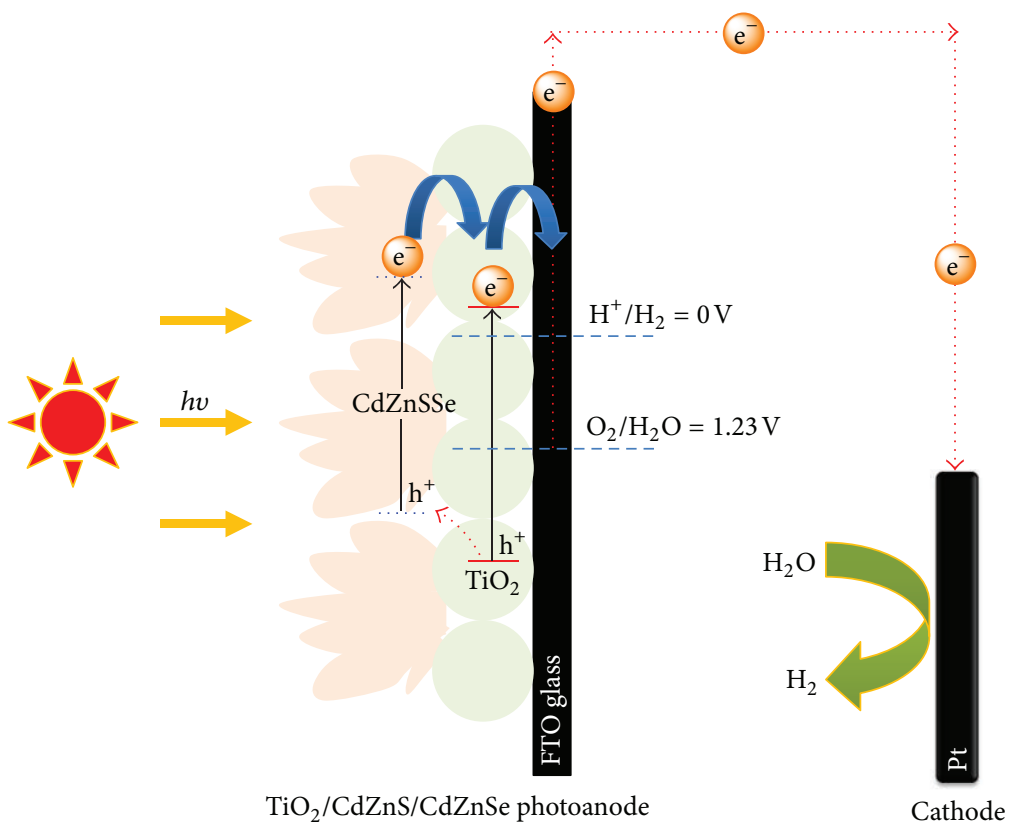

SCHEME 1: Sketch showing the PECs for water splitting.

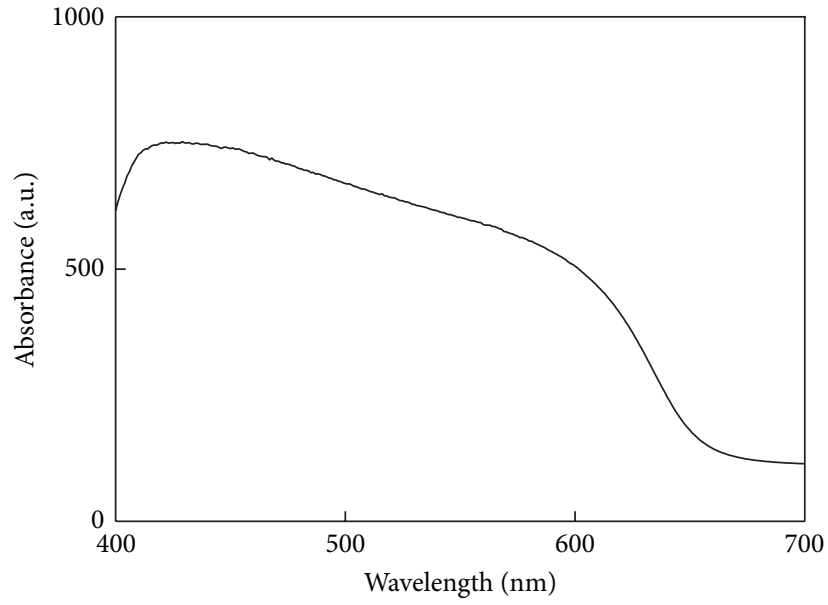

(a)

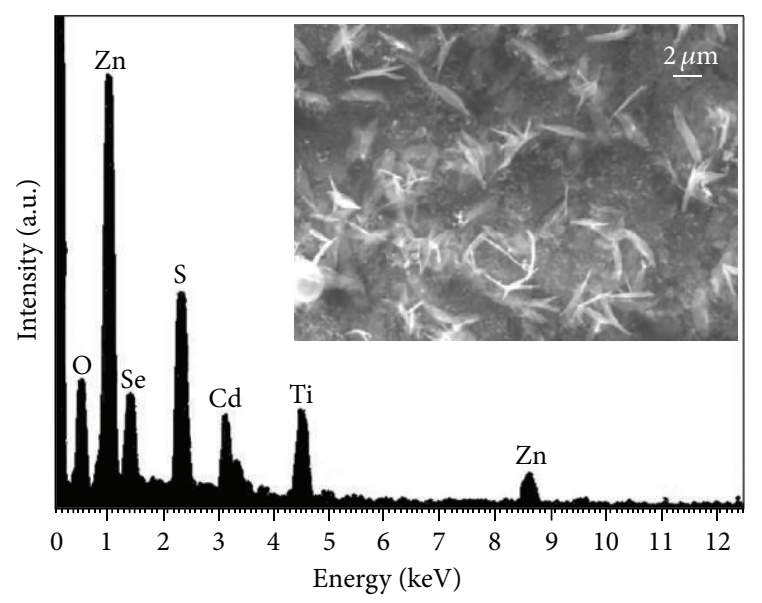

(b)

FIgURE 1: (a) Absorption spectra, (b) EDS spectra of $\mathrm{TiO}_{2} / \mathrm{CdZnS}_{(5)} / \mathrm{CdZnSe}_{(2)}$ electrode (inset to (b): SEM image).

an advantage of negligible photocorrosion effect on QDs. Moreover, $\mathrm{Na}_{2} \mathrm{~S}$ in solution acted as a hole scavenger and it was oxidized into $\mathrm{S}_{2}{ }^{2-}$, which was reduced back to $\mathrm{S}_{2}{ }^{-}$by $\mathrm{Na}_{2} \mathrm{SO}_{3}$ [26]. Photogenerated holes irreversibly oxidized the reducing agents $\left(\mathrm{Na}_{2} \mathrm{~S} / \mathrm{Na}_{2} \mathrm{SO}_{3}\right)$ instead of water, providing the photocatalyst electron rich and an enhanced $\mathrm{H}_{2}$ evolution reaction. The reaction mechanism of each electrode can be described as follows.

Anode:

$$
\begin{gathered}
\mathrm{TiO}_{2} / \mathrm{CdZnS}_{(m)} / \mathrm{CdZnSe}_{(n)}+h v \longrightarrow \mathrm{h}^{+}+\mathrm{e}^{-} \\
\mathrm{SO}_{3}{ }^{2-}+2 \mathrm{OH}^{-}+2 \mathrm{~h}^{+} \longrightarrow \mathrm{SO}_{4}{ }^{2-}+2 \mathrm{H}^{+}
\end{gathered}
$$

$$
\begin{gathered}
2 \mathrm{~S}^{2-}+2 \mathrm{~h}^{+} \longrightarrow \mathrm{S}_{2}{ }^{2-} \\
\mathrm{S}_{2}{ }^{2-}+\mathrm{SO}_{3}{ }^{2-} \longrightarrow \mathrm{S}_{2} \mathrm{O}_{3}{ }^{2-}+\mathrm{S}^{2-} \\
\mathrm{SO}_{3}{ }^{2-}+\mathrm{S}^{2-}+2 \mathrm{~h}^{+} \longrightarrow \mathrm{S}_{2} \mathrm{O}_{3}{ }^{2-}
\end{gathered}
$$

Cathode:

$$
2 \mathrm{e}^{-}+2 \mathrm{H}_{2} \mathrm{O} \longrightarrow \mathrm{H}_{2}+2 \mathrm{OH}^{-}
$$

3.2. Photocatalytic Hydrogen Evolution. It was evident from linear sweep voltammetry (LSV) characteristic curves (Figure 3(a)), under one sun light illumination (AM 1.5, $100 \mathrm{~mW} \mathrm{~cm}^{-2}$ ), the $\mathrm{TiO}_{2} / \mathrm{CdZnS}_{(5)} / \mathrm{CdZnSe}_{(2)}$ electrode 


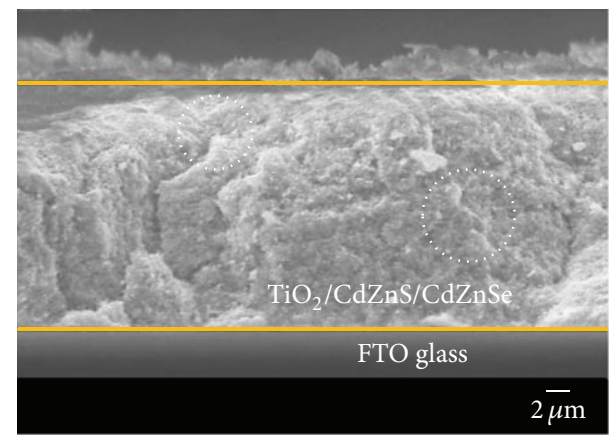

FIgURE 2: The SEM image showing the cross-sectional view of a $\mathrm{TiO}_{2} / \mathrm{CdZnS} / \mathrm{CdZnSe}$ photoelectrode. The dotted circles represent the cross-sectional view of cascade structures.

produced a noteworthy limiting photocurrent density value of $9.7 \mathrm{~mA} \mathrm{~cm}^{-2}$ at $-0.9 \mathrm{~V}$ versus SCE, which was superior to those produced by most QDs-sensitized electrodes [10-18]. Such a high photocurrent density can be attributed to the cascade structure of $\mathrm{CdZnS}_{(5)} / \mathrm{CdZnSe}_{(2)}$. Although electrodes having higher limiting photocurrent densities have been reported [14-18], their relative high applied voltages $(0.356$ and $-0.574 \mathrm{~V}$ versus SCE) are disadvantageous over ours. The as-prepared electrode required a very low onset potential $(-0.9 \mathrm{~V})$, implying that it required less energy to drive the reaction. The negative shift of the onset potential confirms the enhanced charge transfer which may possibly be due to a high recombination rate and kinetic hindrance by $\mathrm{CdZnS}_{(5)} / \mathrm{CdZnSe}_{(2)}$ sensitization [16]. We further conducted amperometric $I-t$ measurements to examine the photocatalytic activity and photoresponses of the $\mathrm{TiO}_{2} / \mathrm{CdZnS}_{(5)} / \mathrm{CdZnSe}_{(2)}$ electrode (Figure 3(b)). Notably, the potential set at $-0.9 \mathrm{~V}$ produced stable limiting photocurrent density. Upon illumination, spiked photoresponses of $9.7 \mathrm{~mA} \mathrm{~cm}^{-2}$ were observed, which was much higher than the dark current density $\left(\sim 50 \mu \mathrm{A} \mathrm{cm}^{-2}\right)$. The reproducibility of the photoresponses was also excellent (relative standard deviation $0.4 \%$ from 10 replicated measurements). The photoresponses were fast $(<4 \mathrm{~s})$, revealing their promising photocatalytic activity. By using (7) [27], the value of $\eta$ for the data obtained from Figure 3 is as follows:

$$
\begin{aligned}
\eta(\%) & =\left[\frac{(\text { total power output }- \text { electrical power output })}{(\text { light power input })}\right] \\
& \times 100 \% \\
& =J_{p}\left[\frac{\left(E_{\mathrm{rev}}^{0}-\left|E_{\text {app }}\right|\right)}{J_{\text {light }}}\right] \times 100 \%,
\end{aligned}
$$

where, $J_{p}$ is the photocurrent density $\left(\mathrm{mA} \mathrm{cm}^{-2}\right), J_{p} E_{\mathrm{rev}}^{0}$ is the total power output, $J_{p}\left|E_{\text {app }}\right|$ is the electrical power input, and $J_{\text {light }}$ is the power density of incident light $\left(100 \mathrm{~mW} \mathrm{~cm}^{-2}\right) . E_{\text {rev }}^{0}(1.23 \mathrm{~V} / \mathrm{NHE})$ is the standard reversible potential for water splitting. The applied voltage is calculated as $0.48 \mathrm{~V}$ using $E_{\text {app }}=\left|E_{\text {meas }}-E_{\text {aoc }}\right|$, where $E_{\text {meas }}$ is the working electrode potential at which photocurrent was measured under illumination and $E_{\mathrm{aoc}}$ is the potential measured at this working electrode under open circuit potential (OCP) and same experimental conditions, respectively. As shown in Figure 3(c), a maximum $\eta$ value of $7.3 \%$ was achieved at an $E_{\text {app }}$ of $0.48 \mathrm{~V}$. We also recorded $\eta$ values at various $E_{\text {app }}$ values from three different batches of $\mathrm{TiO}_{2} / \mathrm{CdZnS}_{(5)} / \mathrm{CdZnSe}_{(2)}$ electrodes, revealing $\eta$ of $7.3 \pm 0.1 \%$, which is superior to those (e.g., 3.67\%) [11-13] of other QDs-sensitized $\mathrm{TiO}_{2}$ electrodes [1116]. Relative to some reported electrodes such as $\mathrm{TiO}_{2} / \mathrm{CdS}$ $\left(6.4 \mathrm{mmol} \cdot \mathrm{h}^{-1} \cdot \mathrm{g}^{-1}\right)$ and CdSe/CdS $\left(40 \mathrm{mmol} \cdot \mathrm{h}^{-1} \cdot \mathrm{g}^{-1}\right)[17$, 18], our QDs-sensitized electrodes provided a higher $\mathrm{H}_{2}$ generation rate of $172.8 \mathrm{mmol} \cdot \mathrm{h}^{-1} \cdot \mathrm{g}^{-1}(n=3)$. However, in many PECs competing side reactions dominate, resulting in different products and less than ideal faradaic efficiency. If we consider an average current of $9.7 \mathrm{~mA} \mathrm{~cm}^{-2}$ flowing through the circuit, one would expect to observe $\mathrm{H}_{2}$ formation at a theoretical rate of $200.9 \mathrm{mmol} \cdot \mathrm{h}^{-1} \cdot \mathrm{g}^{-1}$ (at $25^{\circ} \mathrm{C}$ ). The observed $\mathrm{H}_{2}$ rate of $172.8 \mathrm{mmol} \cdot \mathrm{h}^{-1} \cdot \mathrm{g}^{-1}$ accounts for $86 \%$ of the amount predicted on the basis of current flow.

To further quantify the performance of PECs incorporating $\mathrm{TiO}_{2} / \mathrm{CdZnS}_{(5)} / \mathrm{CdZnSe}_{(2)}$ electrodes, their IPCE values were acquired in the wavelength range of 400$700 \mathrm{~nm}$ (Figure 3(d)), [10, 16, 27, 28]. The IPCE values were determined from [16]

$$
\text { IPCE }=\frac{\left(1240 \times I_{\mathrm{SC}}\right)}{\left(\lambda \times J_{\text {light }}\right)},
$$

where, $I_{\mathrm{SC}}$ is the photocurrent density, $\lambda$ is the incident light wavelength, and $J_{\text {light }}$ is the measured irradiance. The $\mathrm{TiO}_{2} / \mathrm{CdZnS}_{(5)} / \mathrm{CdZnSe}_{(2)}$ electrodes exhibited a pronounced IPCE value of $80 \%$ at $500 \mathrm{~nm}$. We further estimated the $I_{\mathrm{SC}}$ values from the following [28]:

$$
I_{\mathrm{SC}}=\int q F(\lambda) \operatorname{IPCE}(\lambda) \mathrm{d} \lambda,
$$

where $q$ is the electron charge and $F(\lambda)$ is the incident photon flux of the solar light. The value of $I_{\mathrm{SC}}$ calculated from the maximum IPCE value at AM 1.5 photon flux was ca. $\sim 9.74 \mathrm{~mA} \mathrm{~cm}^{-2}$, which was quite close to the $I_{\mathrm{SC}}$ value $\left(\sim 9.7 \mathrm{~mA} \mathrm{~cm}^{-2}\right)$ measured from LSV measurements. The close agreement between $I_{\mathrm{SC}}$ values obtained from IPCE spectra and $I-V$ curves indicates that the photocurrent was indeed generated from the electrode upon illumination [28]. Moreover, photochemical stability of the $\mathrm{TiO}_{2} / \mathrm{CdZnS}_{(5)} / \mathrm{CdZnSe}_{(2)}$ electrodes in sacrificial electrolyte was quite appreciable as negligible changes in the $I-V$ curve was observed over 100 cycles (not shown). Table 1 summarizes the LSV measurements of various electrodes employed for solar water splitting under the same conditions. These results revealed that the cascade structure of $\mathrm{CdZnS}_{(m)} / \mathrm{CdZnSe}_{(n)}$ played a major role in determining the values of $\eta$. Upon increasing the CdZnS layers, the $\eta$ value increased and reached a plateau at $m=5$, when $n$ was 


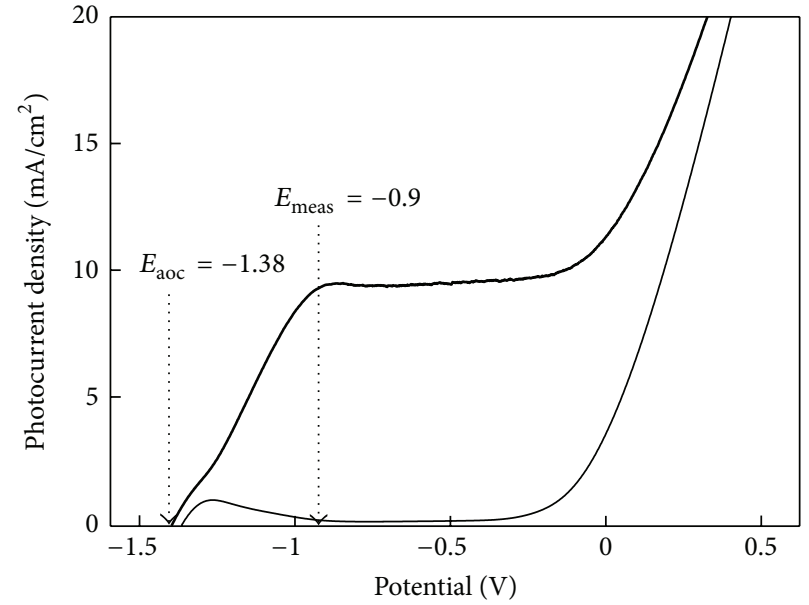

- (A)

(B)

(a)

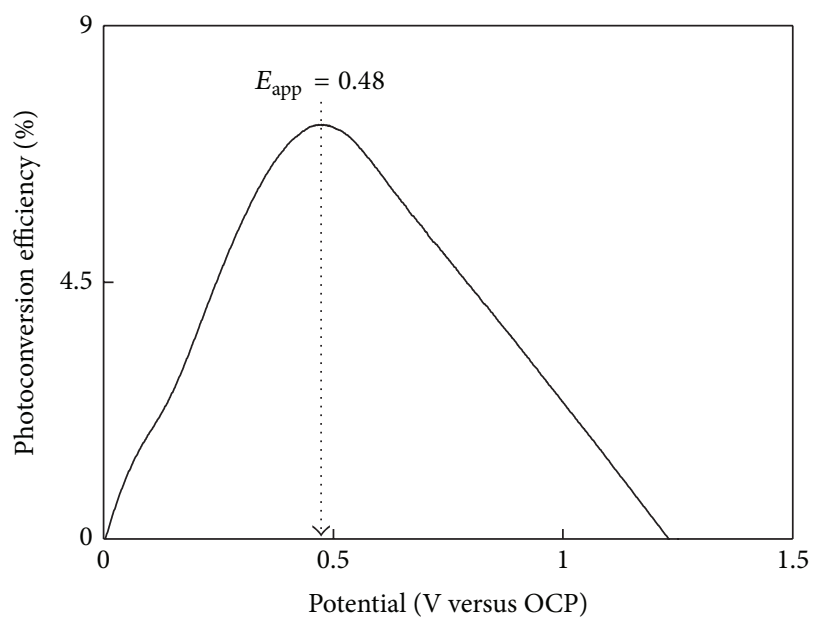

(c)

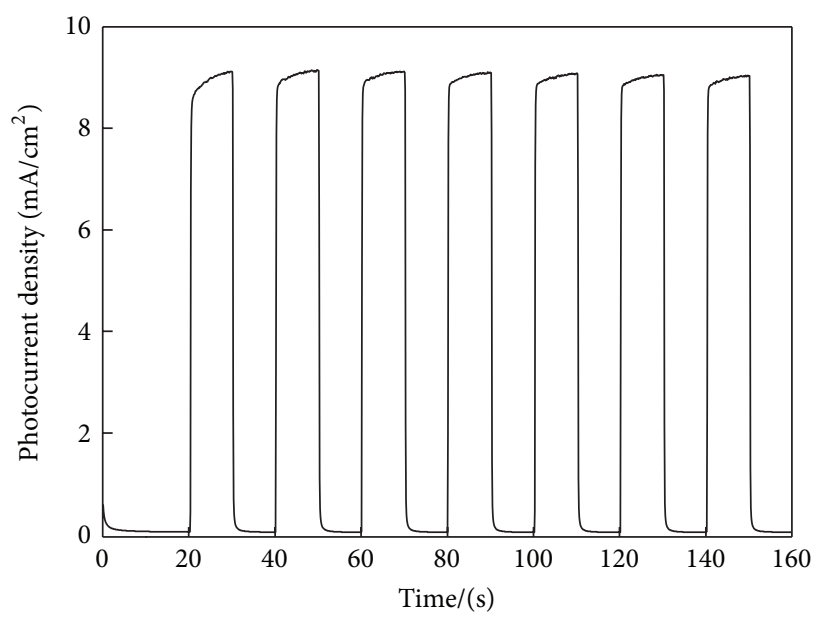

(b)

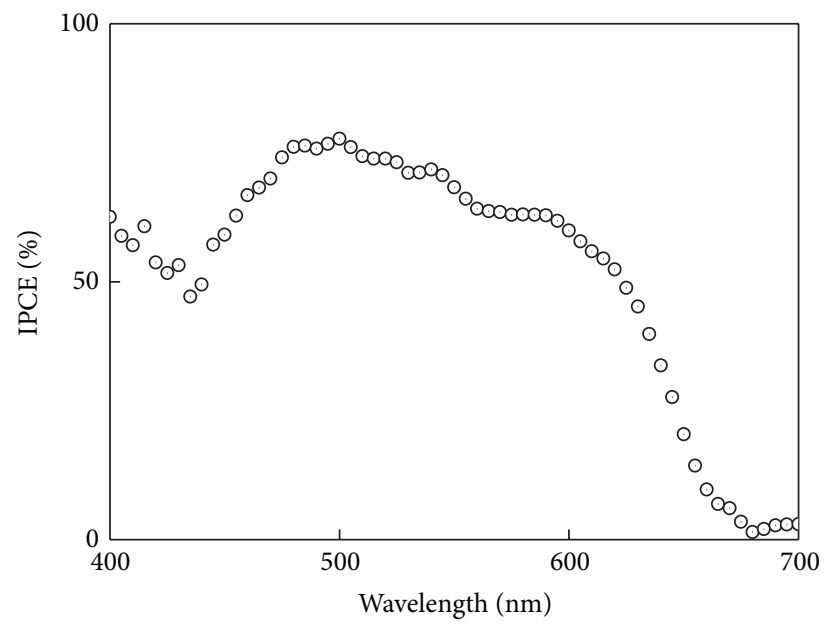

(d)

Figure 3: Performance of $\mathrm{TiO}_{2} / \mathrm{CdZnS}_{(5)} / \mathrm{CdZnSe}_{(2)}$ electrodes. (a) LSV characteristic curves (A) in the dark and (B) under AM 1.5 illumination. (b) Amperometric photoresponses obtained with on/off light cycles at $100 \mathrm{~mW} \mathrm{~cm}^{-2}$ at a fixed potential of $-0.9 \mathrm{~V}$, (c) photoconversion efficiency versus applied voltage ( $E_{\text {app }}$, with respect to OCP), and (d) IPCE spectra. Electrolyte: $2 \mathrm{M} \mathrm{Na}_{2} \mathrm{~S}+0.25 \mathrm{M} \mathrm{Na}_{2} \mathrm{SO}_{3}$ ( $\mathrm{pH}=13.0)$.

kept 2. The absorption spectra results (Figure 4) validate that the generation of different photocurrent densities is a vital factor responsible for superior light harvesting efficiency of these electrodes. The band gaps of the as-resulting $\mathrm{CdZnS}$ and $\mathrm{CdZnSe}$ QDs were 2.40 and $1.85 \mathrm{eV}$, respectively. Thus, the insertion of CdZnS layer between $\mathrm{TiO}_{2}$ and $\mathrm{CdZnSe}$ of the cascade structure elevates the conduction band edge of CdZnSe, and thus provides higher driving force for the injection of excited electrons out of CdZnSe layer. However, upon increasing the values of $m$ from 5 and $n$ from 2 (the thickness of the QDs layer), the photoexcited electrons could not be effectively injected into the $\mathrm{TiO}_{2}$ conduction band, likely due to the presence of additional QDs. Nevertheless, the position of the absorption peak exhibits a red shift with increase in the number of $\mathrm{CdZnSe}_{(n)}$ layers, mainly due to the size quantization and confinement effects.

We further measured OCP of the $\mathrm{TiO}_{2} / \mathrm{CdZnS}_{(5)}$, $\mathrm{TiO}_{2} / \mathrm{CdZnS}_{(5)} / \mathrm{CdZnSe}_{(2)}$, and $\mathrm{TiO}_{2} / \mathrm{CdZnSe}_{(2)}$ electrodes under dark conditions (Figure 5). The OCP values were -1.46 and $-1.33 \mathrm{~V}$ versus SCE for $\mathrm{TiO}_{2} / \mathrm{CdZnS}_{(5)}$ and $\mathrm{TiO}_{2} / \mathrm{CdZnSe}_{(2)}$ electrodes, indicating that CdZnS had a higher Fermi level than that of CdZnSe. When the $\mathrm{CdZnS} / \mathrm{CdZnSe}$ junction is formed, electrons will flow from CdZnS to CdZnSe until the Fermi energy of the electrons in the CdZnS equals to that of CdZnSe. Band offset occurred at the interface of CdZnS/CdZnSe electrodes under illumination, causing a shift of Fermi level $(-1.38 \mathrm{~V}$ versus SCE) in the $\mathrm{TiO}_{2} / \mathrm{CdZnS}_{(5)} / \mathrm{CdZnSe}_{(2)}$ electrode. As 
TABLE 1: Photocurrent densities, applied voltages (vs. SCE), and efficiencies ( $\eta$ ) of the $\mathrm{TiO}_{2} / \mathrm{CdZnS}_{(m)} / \mathrm{CdZnSe}_{(n)}$ electrodes and those of other previously reported $\mathrm{TiO}_{2}$-based electrodes.

\begin{tabular}{|c|c|c|c|c|}
\hline Electrodes & Photocurrent density $\left(\mathrm{mA} \mathrm{cm}^{-2}\right)$ & Applied voltage (V) & $\eta(\%)^{\mathrm{a}}$ & Reference \\
\hline $\mathrm{CdZnS}_{(3)} / \mathrm{CdZnSe}_{(2)}$ & 5.9 & -0.8 & 3.89 & This work \\
\hline $\mathrm{CdZnS}_{(4)} / \mathrm{CdZnSe}_{(2)}$ & 7.3 & -0.87 & 5.34 & This work \\
\hline $\mathrm{CdZnS}_{(5)} / \mathrm{CdZnSe}_{(2)}$ & 9.7 & -0.9 & 7.27 & This work \\
\hline $\mathrm{CdZnS}_{(6)} / \mathrm{CdZnSe}_{(2)}$ & 8.9 & -0.88 & 6.49 & This work \\
\hline $\mathrm{CdZnS}_{(7)} / \mathrm{CdZnSe}_{(2)}$ & 8.4 & -0.87 & 5.98 & This work \\
\hline $\mathrm{CdZnS}_{(5)} / \mathrm{CdZnSe}_{(0)}$ & 2.9 & -1.0 & 2.47 & This work \\
\hline $\mathrm{CdZnS}_{(5)} / \mathrm{CdZnSe}_{(1)}$ & 7.9 & -0.94 & 6.31 & This work \\
\hline $\mathrm{CdZnS}_{(5)} / \mathrm{CdZnSe}_{(3)}$ & 7.6 & -0.91 & 5.70 & This work \\
\hline $\mathrm{CdZnS}_{(0)} / \mathrm{CdZnSe}_{(2)}$ & 4.6 & -1.02 & 4.01 & This work \\
\hline $\mathrm{CdSe}$ & 2.75 & -0.494 & $\mathrm{NA}^{\mathrm{b}}$ & {$[16]$} \\
\hline $\mathrm{TiO}_{2} / \mathrm{CdS} \& \mathrm{CdSe}$ & 12 & 0.356 & NA & {$[14]$} \\
\hline $\mathrm{TiO}_{2} / \mathrm{CdS} / \mathrm{CdSe}$ & 14.9 & -0.544 & NA & {$[15]$} \\
\hline $\mathrm{CdZnS}_{(3)} / \mathrm{CdZnSe}_{(2)}$ & 5.5 & -0.644 & 3.67 & {$[11]$} \\
\hline
\end{tabular}

ander AM $1.5\left(100 \mathrm{~mW} \mathrm{~cm}^{-2}\right)$ illumination of light. ${ }^{\mathrm{b}}$ Not available.

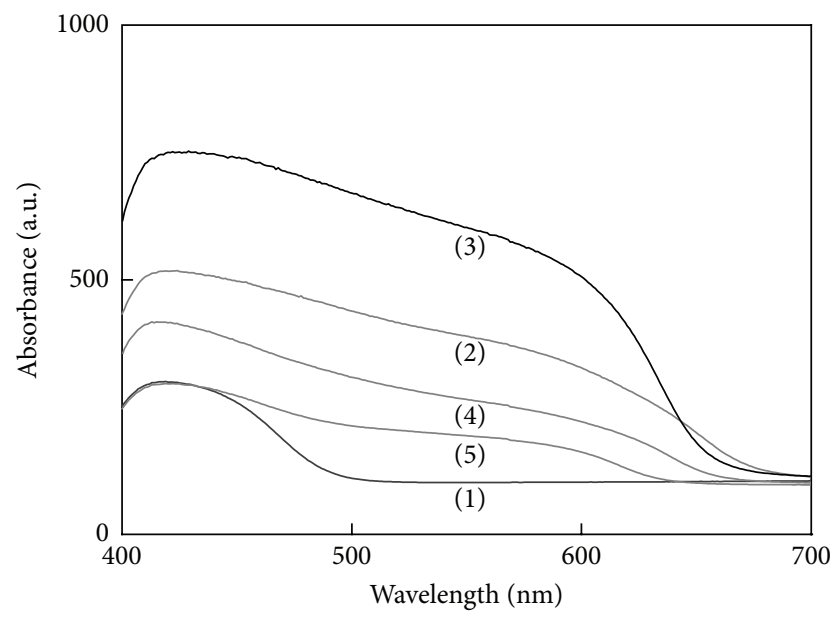

FIgURE 4: UV-vis absorption spectra of $\mathrm{TiO}_{2} / \mathrm{CdZnS}_{(5)} / \mathrm{CdZnSe}_{(n)}$ electrodes. (1) $\mathrm{TiO}_{2} /(\mathrm{CdZnS})_{5}$, (2) $\mathrm{TiO}_{2} /(\mathrm{CdZnS})_{5} /(\mathrm{CdZnSe})_{1}$, (3) $\mathrm{TiO}_{2} /(\mathrm{CdZnS})_{5} /(\mathrm{CdZnSe})_{2},(4) \mathrm{TiO}_{2} /(\mathrm{CdZnS})_{5} /(\mathrm{CdZnSe})_{3}$, (5) $\mathrm{TiO}_{2} /(\mathrm{CdZnS})_{5} /(\mathrm{CdZnSe})_{4}$.

a result, higher $J_{S C}$ value $\left(9.7 \mathrm{~mA} \mathrm{~cm}^{-2}\right)$ was generated in the $\mathrm{TiO}_{2} / \mathrm{CdZnS}_{(5)} / \mathrm{CdZnSe}_{(2)}$ than those $\left(2.9\right.$ and $\left.4.6 \mathrm{~mA} \mathrm{~cm}^{-2}\right)$ of the $\mathrm{TiO}_{2} / \mathrm{CdZnS}_{(5)}$ and $\mathrm{TiO}_{2} / \mathrm{CdZnSe}_{(2)}$ electrodes.

To highlight the features of the $\mathrm{TiO}_{2} / \mathrm{CdZnS}_{(5)} / \mathrm{CdZnSe}_{(2)}$ electrodes, we have listed some of the most effective electrodes for solar water splitting (Table 1). The as-prepared $\mathrm{TiO}_{2} / \mathrm{CdZnS}_{(5)} / \mathrm{CdZnSe}_{(2)}$ electrodes provide the highest $\eta$ value as a result of their lowest applied voltage and highcurrent density. However, they had a negative applied voltage versus SCE, mainly because their Fermi energy level will be changed due to the band realignment of $\mathrm{TiO}_{2}$ by $\mathrm{CdZnS}$ and $\mathrm{CdZnSe}$ sensitization. These results also reveal that the photocurrents and applied voltage are highly dependent on the structure of the photoelectrodes.

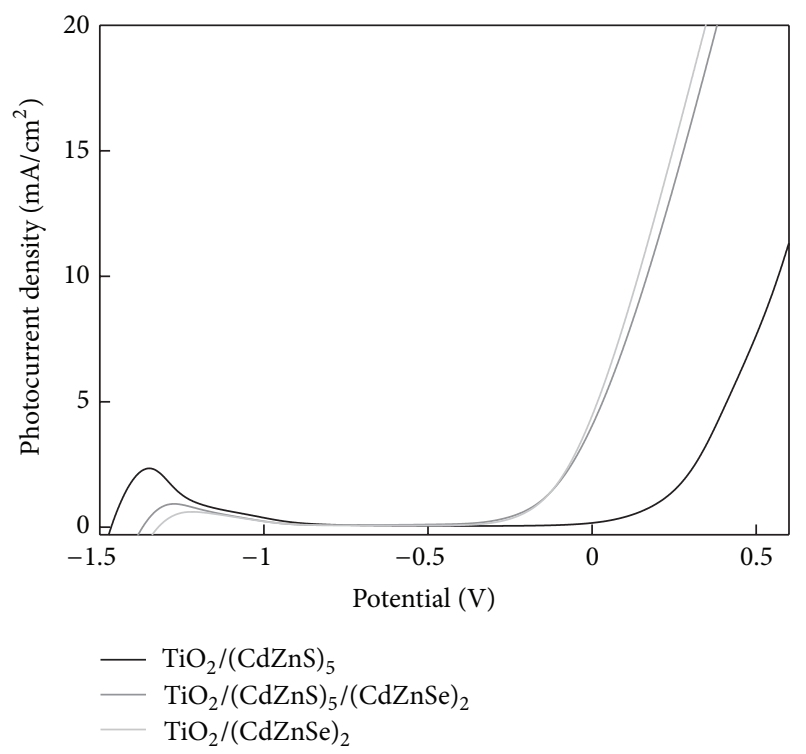

FIGURE 5: LSV characteristic curves of three different electrodes under dark conditions.

\section{Conclusions}

In conclusion, we have employed $\mathrm{TiO}_{2} / \mathrm{CdZnS}_{(5)} / \mathrm{CdZnSe}{ }_{(2)}$ electrodes for highly efficient solar water splitting. These electrodes yielded a significant photocurrent density of $9.7 \mathrm{~mA} \mathrm{~cm}^{-2}$ at $-0.9 \mathrm{~V}$ versus SCE, mainly attributing to high light harvest efficiency (e.g., IPCE of $80 \%$ at $500 \mathrm{~nm}$ ). To the best of our knowledge, the electrodes provided the highest value of $\eta$ for the solar water splitting among QDsbased photocatalysts, mainly because they provide high photocurrent density at low applied voltage. Although the $\mathrm{TiO}_{2} / \mathrm{CdZnS}_{(5)} / \mathrm{CdZnSe}_{(2)}$ electrodes hold great promise for commercial use in water splitting, further increase in their efficiency is still required. 


\section{Acknowledgments}

The authors thank the National Science Council, Taiwan, for the financial support (NSC 101-2627-M-002-007-). Z. Yang and A. P. Periasamy thank the National Taiwan University for the award of a postdoctoral fellow of the Department of Chemistry, National Taiwan University.

\section{References}

[1] M. Gratzel, "Photoelectrochemical cells," Nature, vol. 414, pp. 338-344, 2001.

[2] L. Schlapbach and A. Zuttel, "Hydrogen-storage materials for mobile applications," Nature, vol. 414, pp. 353-358, 2001.

[3] K. Maeda and K. Domen, "Photocatalytic water splitting: recent progress and future challenges," Journal of Physical Chemistry Letters, vol. 1, no. 18, pp. 2655-2661, 2010.

[4] P. V. Kamat, "Manipulation of charge transfer across semiconductor interface. A criterion that cannot be ignored in photocatalyst design," The Journal of Physical Chemistry Letters, vol. 3, no. 5, pp. 663-672, 2012.

[5] Y. Xu and M. A. A. Schoonen, "The absolute energy positions of conduction and valence bands of selected semiconducting minerals," American Mineralogist, vol. 85, no. 3-4, pp. 543-556, 2000.

[6] J. H. Park, S. Kim, and A. J. Bard, "Novel carbon-doped $\mathrm{TiO}_{2}$ nanotube arrays with high aspect ratios for efficient solar water splitting," Nano Letters, vol. 6, no. 1, pp. 24-28, 2006.

[7] A. Wolcott, W. A. Smith, T. R. Kuykendall, Y. Zhao, and J. Z. Zhang, "Photoelectrochemical water splitting using dense and aligned $\mathrm{TiO}_{2}$ nanorod arrays," Small, vol. 5, no. 1, pp. 104-111, 2009.

[8] M. Kitano, M. Matsuoka, M. Ueshima, and M. Anpo, "Recent developments in titanium oxide-based photocatalysts," Applied Catalysis A: General, vol. 325, no. 1, pp. 1-14, 2007.

[9] O. Khaselev and J. A. Turner, "A monolithic photovoltaicphotoelectrochemical device for hydrogen production via water splitting," Science, vol. 280, no. 5362, pp. 425-427, 1998.

[10] H. M. Chen, C. K. Chen, Y. C. Chang et al., "Quantum dot monolayer sensitized $\mathrm{ZnO}$ nanowire-array photoelectrodes: true efficiency for water splitting," Angewandte ChemieInternational Edition, vol. 49, no. 34, pp. 5966-5969, 2010.

[11] C. F. Chi, Y. L. Lee, and H. S. Weng, "A CdS-modified $\mathrm{TiO}_{2}$ nanocrystalline photoanode for efficient hydrogen generation by visible light," Nanotechnology, vol. 19, no. 12, Article ID 125704, 2008 .

[12] L. M. Peter, D. J. Riley, E. J. Tull, and K. G. U. Wijayantha, "Photosensitization of nanocrystalline $\mathrm{TiO}_{2}$ by self-assembled layers of CdS quantum dots," Chemical Communications, no. 10, pp. 1030-1031, 2002.

[13] I. Robel, V. Subramanian, M. Kuno, and P. V. Kamat, "Quantum dot solar cells. Harvesting light energy with CdSe nanocrystals molecularly linked to mesoscopic $\mathrm{TiO}_{2}$ films," Journal of the American Chemical Society, vol. 128, no. 7, pp. 2385-2393, 2006.

[14] G. Wang, X. Yang, F. Qian, J. Z. Zhang, and Y. Li, "Double-sided $\mathrm{CdS}$ and $\mathrm{CdSe}$ quantum dot co-sensitized $\mathrm{ZnO}$ nanowire arrays for photoelectrochemical hydrogen generation," Nano Letters, vol. 10, no. 3, pp. 1088-1092, 2010.

[15] Y. L. Lee, C. F. Chi, and S. Y. Liau, "CdS/CdSe co-sensitized $\mathrm{TiO}_{2}$ photoelectrode for efficient hydrogen generation in a photoelectrochemical cell," Chemistry of Materials, vol. 22, no. 3, pp. 922-927, 2010.

[16] J. Hensel, G. Wang, Y. Li, and J. Z. Zhang, "Synergistic effect of CdSe quantum dot sensitization and nitrogen doping of $\mathrm{TiO}_{2}$ nanostructures for photoelectrochemical solar hydrogen generation," Nano Letters, vol. 10, no. 2, pp. 478-483, 2010.

[17] N. Chouhan, C. L. Yeh, S. F. Hu et al., "Array of CdSe QD-sensitized $\mathrm{ZnO}$ nanorods serves as photoanode for water splitting," Journal of the Electrochemical Society, vol. 157, no. 10, pp. B1430-B1433, 2010.

[18] L. Amirav and A. P. Alivisatos, "Photocatalytic hydrogen production with tunable nanorod heterostructures," Journal of Physical Chemistry Letters, vol. 1, no. 7, pp. 1051-1054, 2010.

[19] A. J. Nozik, “Quantum dot solar cells," Physica E, vol. 14, pp. 115120, 2002.

[20] B. A. Gregga and M. C. Hanna, "Comparing organic to inorganic photovoltaic cells: theory, experiment, and simulation," Journal of Applied Physics, vol. 93, pp. 3605-3614, 2003.

[21] Z. Yang, C. Y. Chen, C. W. Liu, and H. T. Chang, "Electrocatalytic sulfur electrodes for CdS/CdSe quantum dot-sensitized solar cells," Chemical Communications, vol. 46, no. 30, pp. 54855487, 2010.

[22] G. Y. Lan, Z. Yang, Y. W. Lin, Z. H. G. Lin, H. Y. Liao, and H. T. Chang, "A simple strategy for improving the energy conversion of multilayered CdTe quantum dot-sensitized solar cells," Journal of Materials Chemistry, vol. 19, no. 16, pp. 23492355, 2009.

[23] Y. L. Lee and Y. S. Lo, "Highly efficient quantum-dot-sensitized solar cell based on co-sensitization of CdS/CdSe," Advanced Functional Materials, vol. 19, no. 4, pp. 604-609, 2009.

[24] N. N. Rao and S. Dube, "Photoelectrochemical generation of hydrogen using organic pollutants in water as sacrificial electron donors," International Journal of Hydrogen Energy, vol. 21, no. 2, pp. 95-98, 1996.

[25] A. Thibert, F. Andrew Frame, E. Busby, M. A. Holmes, F. E. Osterloh, and D. S. Larsen, "Sequestering high-energy electrons to facilitate photocatalytic hydrogen generation in $\mathrm{CdSe} / \mathrm{CdS}$ nanocrystals," The Journal of Physical Chemistry Letters, vol. 2, no. 21, pp. 2688-2694, 2011.

[26] X. B. Chen, S. H. Shen, L. J. Guo, and S. S. Mao, "Semiconductorbased photocatalytic hydrogen generation," Chemical Reviews, vol. 110, no. 11, pp. 6503-6570, 2010.

[27] G. K. Mor, K. Shankar, M. Paulose, O. K. Varghese, and C. A. Grimes, "Enhanced photocleavage of water using titania nanotube arrays," Nano Letters, vol. 5, no. 1, pp. 191-195, 2005.

[28] Y. Chiba, A. Islam, Y. Watanabe, R. Komiya, N. Koide, and L. Han, "Dye-sensitized solar cells with conversion efficiency of 11.1\%," Japanese Journal of Applied Physics, vol. 45, no. 24-28, pp. L638-L640, 2006. 

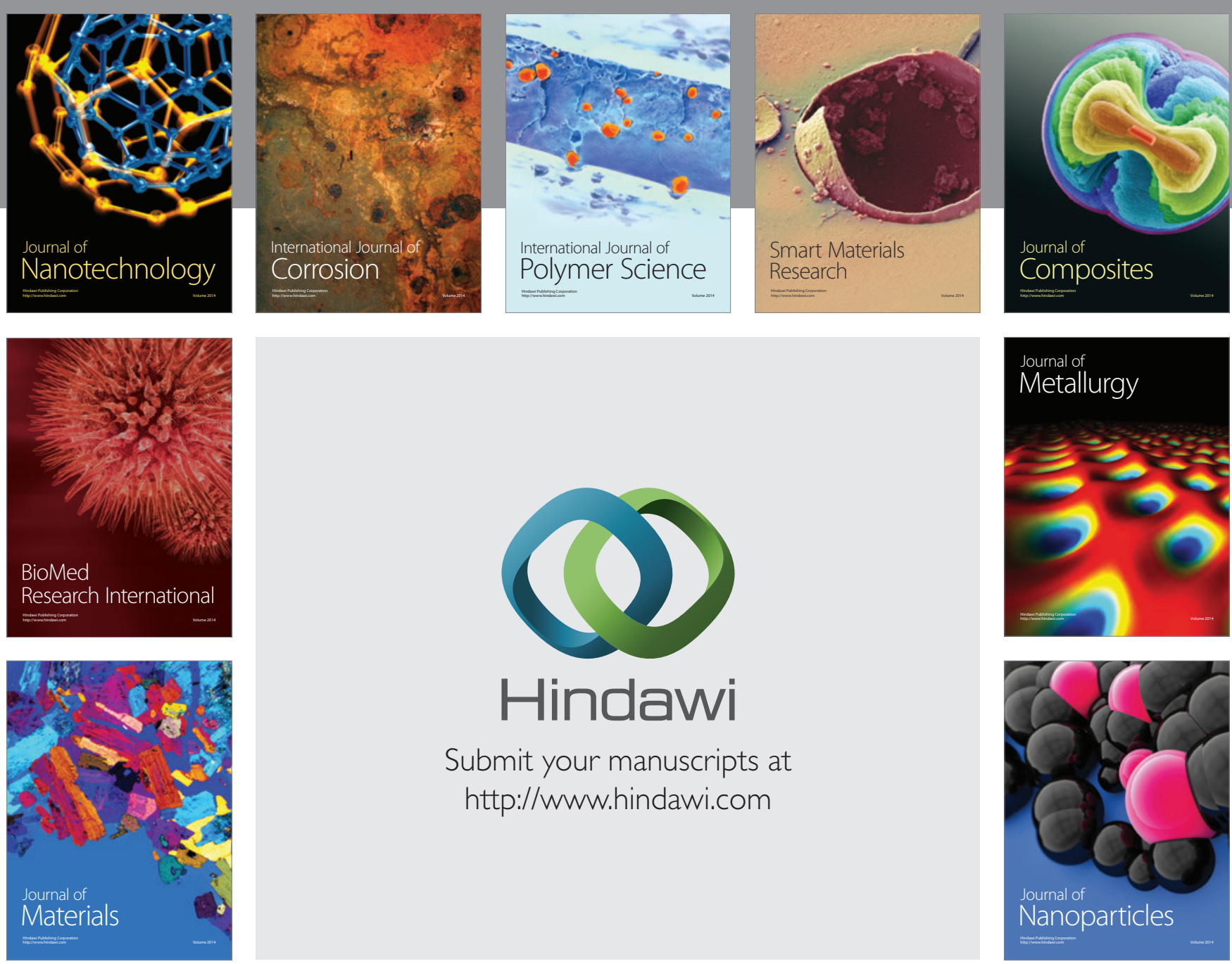

Submit your manuscripts at http://www.hindawi.com
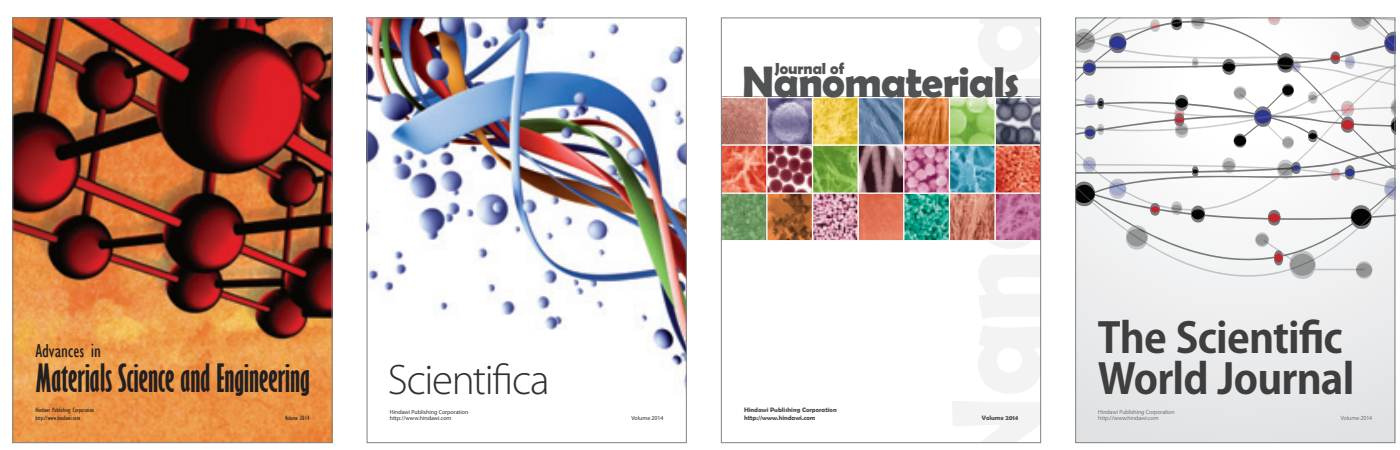

\section{The Scientific World Journal}
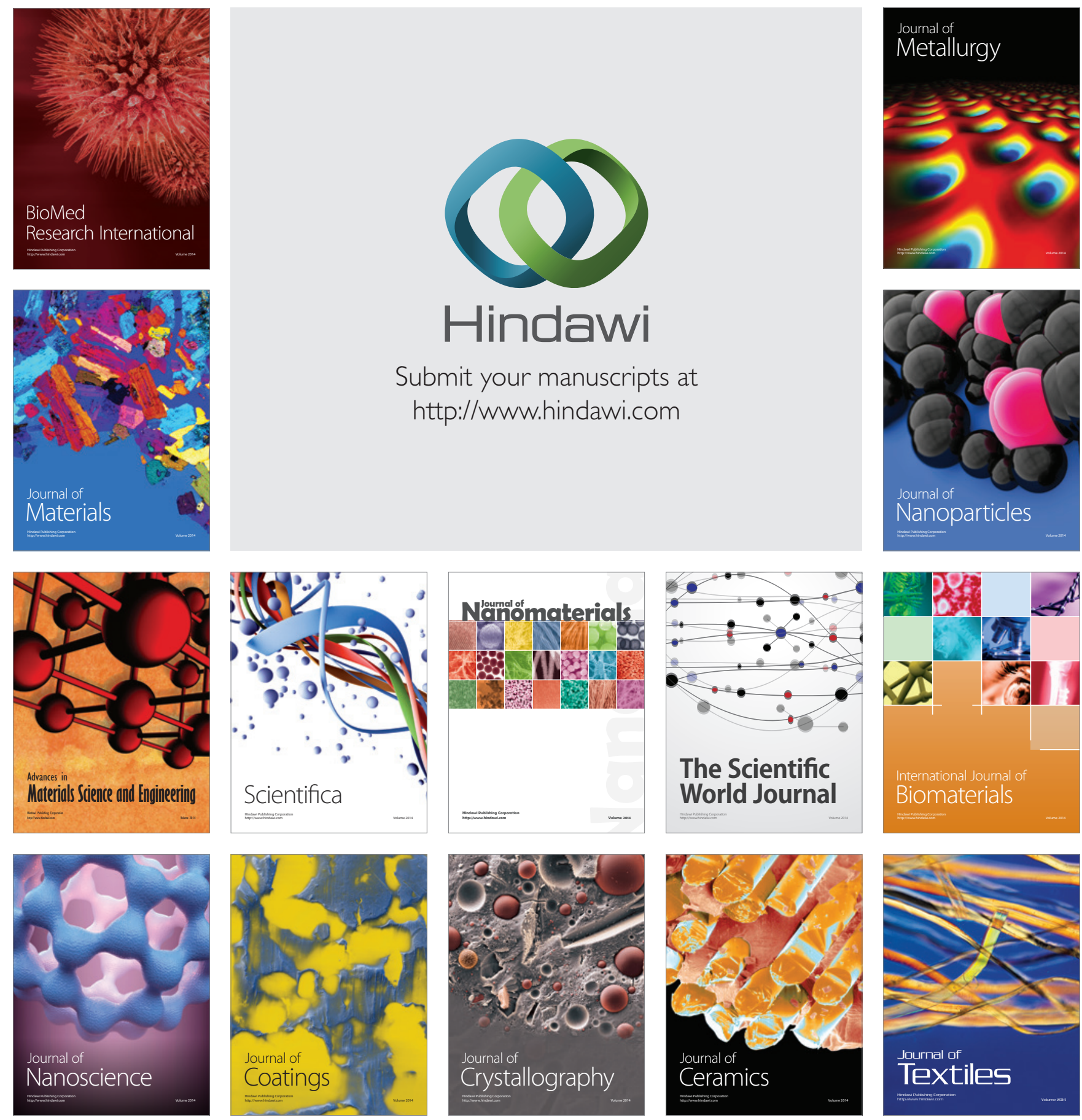